\title{
Groundnut Production and Consumption Rate in Ejigbo Local Government Area of Osun State, Nigeria
}

\section{Ogboru JO and *Ayeni LS}

Department of Agricultural Science, Adeyemi College of Education, Ondo, Nigeria.

ARTICLE INFO

ABSTRACT

Article No.: 031816066

DOI: 10.15580/GJAS.2016.4.031816066

Submitted: 18/03/2016

Accepted: $22 / 03 / 2016$

Published: 08/04/2016

${ }^{\star}$ Corresponding Author

Ayeni LS

E-mail: leye_sam@yahoo.com

Keywords:

Animal dung, mineral fertilizer, cropping pattern, farm size, application method
Groundnut popularly known as peanut is gaining ground in the market as awareness of its nutritive values is being created, hence its production needs to be boosted. A research was carried out to assess the consumption pattern and the impact of fertilizers in boosting groundnut production in Ejigbo Local Government of Osun State. One hundred and twenty farmers were interviewed with structured questionnaires. The ages of the respondents were categorized as $15-30(60 \%), 31-50(48 \%)$, and 51 years and above $(12 \%)$. The study showed that $53.3 \%$ of the respondents were male while $46.7 \%$ were female. All the respondents consume groundnut both in boiled and roasted forms. Only $15 \%$ of the respondents use groundnut to prepare soup called gbegiri while $98 \%$ eat the groundnut cake known as kulikuli. Ninety-two respondents applied fertilizers out of the one hundred and twenty farmers interviewed. Ninety percent of those who applied fertilizers used NPK15:15:15 fertilizer while ten percent used either urea, muriate of potash or animal dung. The methods used by the farmers in applying fertilizers include broadcasting (52.2\%), row (13\%), spot (26.1) and foliar (8.7\%.). Ninety-two percent agreed that the use of fertilizers in growing groundnut increase the yield of groundnut while twenty-eight disagreed. Most farmers were not familiar with the use of organomineral fertilizer in increasing groundnut yield. It is concluded that the type and method of fertilizer application influence the yield of groundnut. 


\section{INTRODUCTION}

Peanut in Local and Global Series (2007) reported that groundnut has nutritive values that contain 25.2, $48.2,4.5,2.1$ and $6 \%$ of protein, oil, starch, soluble sugar, crude fiber and moisture respectively. Local and Global Series (2007) also reported that both the raw and roasted groundnuts contain high amount of calories, protein, fat, carbohydrate, $\mathrm{Ca}, \mathrm{P}, \mathrm{Fe}$, Thiamine, Riboflavine and niacin. Apart from its dietary importance, it can be used as animal feed. Peanut flour is lower in fat than peanut butter and is used as a gluten-free solution (Jauron, 1997). Unhealthy production of peanuts may lead to aflatoxin (Dillehay, 2007).

The Peanut is a leguminous crop, a species in the family Fabaceae. Legumes are known to fix nitrogen through their nodules. Hence, groundnut helps in enriching soil nutrients.

According to literature, Peanuts grow best in light, sandy loan soil. They require five months of warm weather, and 500 to $1,000 \mathrm{~mm}$ (20 to $39 \mathrm{in}$ ) of water. The low water makes groundnut to thrive well in many parts of Nigeria especially the northern parts that experience dry season more than the south. They prefer acidic soils of 5.9-7 pH.

Groundnut is cherished by many people. Groundnut can be eaten in raw, roasted or boiled form. Over the years, production of groundnut has been very prolific and efficient on fertile soils but its cultivation is on decline rate as a result of low soil fertility. In the past, there was groundnut pyramid in the northern part of Nigeria. Due to the fact that people have seen its usefulness, there is a need to increase its productivity by increasing the nutrients content of the soil

A fertilizer is any material or natural synthetic origin other than living materials that is applied to soil or to plant tissues (usually leaves) to supply one or more plant nutrients essential to the growth of plant. Since groundnut are mostly cultivated for their pod and there is the need to produce large amount of peanuts for the masses by the farmer, the appropriate fertilizer should be added to the cultivated soil to improve its fertility, not all fertilizers are required by groundnut.

Application of fertilizers is one of the practical ways to restore plant nutrients and bring life to the severely depleting soils. But small scale farmers who comprise the vast majority of the farming population, have little access to fertilizers and cannot always afford them. The farms must pay two or four times the average world market price for fertilizers. Worsening the problem are weak input and output markets, unfavorable policies, corruption, poor transportation system, limited irrigation and inadequate access to credit (FAO 2007).

To have good quality of groundnut or peanuts, the soil must be given adequate care and nurturing. There is need to access the use of chemical fertilizers in boosting groundnut production in Eijigbo Local Government of Osun state.

The objective of this study was to assess the use of fertilizer by farmers in boosting groundnut production Ejigbo Local Government of Osun state.

\section{MATERIALS AND METHOD}

A total of one hundred and twenty farmers were randomly selected and interviewed in six villages located in Ejigbo Local Government Area in OsunState. An interviewed schedule was designed to measure relevant indicators. Ballot paper was used to select towns and villages used for the research. The questionnaire was self-administered to nonliterate farmers and literate farmers were allowed to fill the questionnaire themselves. Both secondary and primary data were employed to collect useful information from each village to make a total of one hundred and twenty farmers.

The sample villages were: Ola, Isudurin, Isoko, ljimaba, llawo, Ife Odan.

\section{Data Analysis}

The data collected were subjected to statistical analysis, Tables and charts were used.

\section{RESULT AND DISCUSSION}

The selected demography characteristics of the respondents in the study area were Gender, Age, and level of education respectively. 
Table 1: Distribution of Respondents According to Sex

\begin{tabular}{lcc}
\hline \multicolumn{1}{c}{ Sex } & Respondent & Percentage (\%) \\
\hline Male & 64 & 53.3 \\
Female & 56 & 46.7 \\
Total & $\mathbf{1 2 0}$ & $\mathbf{1 0 0}$ \\
\hline
\end{tabular}

In Ejigbo Local Government Area more male participated in Groundnut production than the Female. Some of the women in the selected area might have engaged in another business. The higher number of male to the female could be as a result of cumbersome nature of farming that most female would not be capable of doing.
From table 2 above it could be seen from the table that youths were mostly involved in Groundnut production. The ease of production and high return of the groundnut might have contributed to the high involvement of the youths in production of groundnut. These respondent fall into working class who are young and productive.

Table 3: Educational Background of Respondent

\begin{tabular}{lc}
\hline Level of Education & Respondents \\
\hline No Formal Education & 32 \\
Primary Education & 8 \\
Secondary Education & 24 \\
Tertiary Education & 56 \\
Total & $\mathbf{1 2 0}$ \\
\hline
\end{tabular}

Table 3 above shows that 32 of the respondents had no formal education, 8 had primary education, 24 had secondary education, while 56 had tertiary education. This implies that the farmers have a good educational background in farming.

Table 4:Distribution of Farmers According to the Size of the Farm

\begin{tabular}{|l|c|}
\hline Farm Size & Respondent \\
\hline Less than 1 Acre & 52 \\
\hline $1-5$ acre & 64 \\
\hline $6-10$ acre & 0 \\
\hline Above 10 acre & 4 \\
\hline Total & $\mathbf{1 2 0}$ \\
\hline
\end{tabular}


The distribution of the respondent according to the size of the farm shows that 52 farmers made used of less than 1 acre of land for groundnut production, 64 made use of 1-5 acre of land for groundnut production, no one made use of 6-10 acre of land for groundnut production, while 4 had above 10 acre of farm size. The problem of Land Tenure System and low capital might have contributed immensely to the small acreage of farm size. The data also shows that most of the farmers interviewed were subsistence farmers who might have little capital.

Table 5: Distribution of Farmers According to Cropping System Mono cropping Mixed Cropping

$60 \quad 60$

The above table shows that nearly all the farmers interviewed either planted groundnut alone or mixed it with another crop. 60 of the respondents engaged in (mono cropping), also 60 of the respondents engaged in (mixed cropping) in Ola, Isudurin, Isoko, ljimaba, llawo. acccording to Wandahwa, et al., (2006), groundnut supplements the soil with nitrogen, therefore, other crops can also be planted alongside.

Table 6: Distribution of farmers According to type of Fertilizer

\begin{tabular}{lc}
\hline Fertilizer & No Fertilizer \\
\hline 92 & 28
\end{tabular}

The above table shows that all the farmers made use of fertilizer and the number of farmers that did not apply fertilizer was relatively low. This might be as a result of poor soil fertility in the study area.
Farmers sought additional nutrients by fertilizer application so that the yields of crops would not be limited by plants nutrients.

Table 7: Method of Fertilizer Application

\begin{tabular}{lcc}
\hline Fertilizer application & Respondent & Percentage (\%) \\
\hline Broadcasting method & 48 & 52.2 \\
Ring method & 0 & 0 \\
Row method & 12 & 13.0 \\
Spot method & 24 & 26.1 \\
On leaves method(foliar) & 8 & 8.7 \\
Total & 92 & 100 \\
\hline
\end{tabular}


Table7 shows that farmers used Broadcasting method of fertilizer application. Respondent have a relatively low in Ring method, Row method and on leaves method of applying fertilizer. Broadcasting of fertilizer might cause wastage and increase weeds which might hinder plant growth.

Table 8: Distribution according to Animal Dung applied Do you apply animal dung?

\begin{tabular}{lc}
\hline Applied Animal Dung & No Animal Dung \\
\hline 28 & 92
\end{tabular}

Table 9: Do you Gain when you apply Fertilizer

\begin{tabular}{lc}
\hline YES & NO \\
\hline 96 & 24 \\
\hline
\end{tabular}

Table 10: Organomineral Fertilizer

\begin{tabular}{lc}
\hline YES & NO \\
\hline 0 & 120
\end{tabular}

This shows that respondents that applied animal dung were relatively low, showing that most of the farmers were not familiar with the use of animal dung. Animal dung might not be readily available in the study area because there were not enough cattle in the study area.

The table above shows that most of the farmers gained when they applied fertilizer. This shows that fertilizers help to improve soil fertility and increase yield of crop. The farmers in the study are might depend on fertilizer to increase their production.

Table 10 shows that all the farmers were not familiar with Organomineral fertilizer so they are not making use of it unlike mineral and organic fertilizers. Farmers need to be educated through mass media, individual contact and mass contact method by the village extension agents. The fact that no respondents out of 120 agreed to have used organomineral fertilizer proved that farmers were not familiar with the use of Organomineral fertilizer.

Farmers were interviewed based on their level of peanut consumption. All the respondents consume groundnut both in boiled and roasted forms. Only $15 \%$ of the respondents use groundnut to prepare soup called gbegiri while $98 \%$ eat the groundnut cake known as kulikuli. Groundnut production could be enterprising in the study area since many people consume it.

\section{CONCLUSION}

A research was conducted to assess fertilizer management practices among groundnut farmers in Ejigbo Local Government Area of Osun-State Nigeria.

The ages range of the farmers fall within the youthful age, which indicate that they are still productive and resourceful. Most of the groundnut farmers are peasants who cultivate small acres of land. The farmers practice both sole cropping and mixed cropping. Most of the respondents applied mineral fertilizers and were not aware of Organomineral fertilizers. The farmers are advised to use mineral, organic manures and Organomineral fertilizer interchangeably. Awareness of Organomineral fertilizers need to be created by 
Agricultural Extension Agents. Educated agricultural farmers should be encouraged to go into groundnut production. Agricultural institutions should be established in Ejigbo Local Government. Farmers school day should be encouraged in Ejigbo Local Government. Further studies should be carried out to involve other parts of the states that grow groundnut.

\section{REFERENCES}

Ayeni, L.S. 2011.Effect of Sole and Combined Cocoa Pod Ash, Poultry Manure and NPK 20:10:10 Fertilizer on Soil organic carbon, available $\mathrm{P}$ and forms of nitrogen and of Alfisols in Southwestern Nigeria. International Journal of Agriculture and Soil Science. 1 (3): 77 - 82.

Dillehay, Tom D.2007. "Earliest-known evidence of peanut, cotton and squash farming Agric. Journal 2(1) $25-31$.

Jauron, Richard.1997. Growing peanuts in the Home Garden. Horticullture News".jpm.iastate.edu. .

Peanut in Local and Global Food System,2007. Series Report, No 5, Departemnt of Anthropology, University of Georgia, 2007][

Wandahwa, P.I., I.M. Tabu, M.K. Kendagor and J.A.rota, 2006. effects of intercropping and fertilizer type on groundnut yield of soybean (Glycine max I. Merrill.J.Agron., 5: 69-73.

Cite this Article: Ogboru JO and Ayeni LS (2016). Groundnut Production and Consumption Rate in Ejigbo Local Government Area of Osun State, Nigeria. Greener Journal of Agricultural Sciences, 6(4): 145-150, http://doi.org/10.15580/GJAS.2016.4.031816066. 